\title{
Hubungan Kecemasan Matematika dan Self-Regulated Learning terhadap Motivasi Siswa Sekolah Menengah Atas dalam Pembelajaran Matematika pada Kelas Virtual
}

\author{
Ignes Febryliani ${ }^{1}$ \\ ${ }^{1}$ Prodi Pendidikan Matematika, Fakultas Keguruan dan Ilmu Pendidikan, Universitas Muhammadiyah Prof. Dr. Hamka, \\ Jl. Tanah Merdeka No.20, RT.11/RW.2, Rambutan, Kec. Ps..Rebo, Jakarta Timur \\ ignesfbryln@gmail.com
}

\begin{abstract}
This research aims to dectect the relation between mathematics anxiety and self-reguated learning on the student motivation in online learning mathematics through a virtual-classes during the COVID-19 period. This type of research uses a quantitative survey method. The samples used in this research are the 300 eleventh-grade high school students of 2020/2021 in Jakarta. The instrument used in this research is a questionnaire that consists of statements about mathematics anxiety, self-reguated learning, and student motivation. The data analysis technique used is product moment correlation analysis and multiple regression analysis. The resultf of this research shows that (1) there isn't any relation between mathematics anxiety and student motivation with a very weak level, (2) there is a relation between self-reguated learning and student motivation with a moderate level, and (3) there is a relation between mathematics anxiety and self-reguated learning on the student motivation with a $30 \%$ influence on the student motivation depend on the mathematics anxiety and self-reguated learning.
\end{abstract}

Keywords: Math Anxiety, Self-Regulated Learning, Stundent Motivation, Virtual Class

\begin{abstract}
Abstrak
Pengkajian ini mempunyai tujuan untuk mendeteksi hubungan antara kecemasan matematika serta self-reguated learning pada motivasi siswa pada pembelajaran matematika secara online melalui kelas virtual pada masa covid-19. Jenis pengkajian ini memakai metode survery kuantitatif. Sampel yang dipakai di pengkajian ini ialah 300 siswa kelas XI sekolah menengah atas pada tahun ajaran 2020/2021 yang ada di daerah Jakarta. Instumen yang dipakai di pengkajian ini yakni kuesioner berisi pernyataan mengenai kecemasan matematika, self regualted dan motivasi siswa. Teknik analisis data yang dilakukan ialah analisis korelasi product moment serta analisis regeresi berganda. Hasil penelitian menunjukan (1) tidak ada hubungan antara kecemasan matematika serta motivasi siswa dengan tingkat hubungannya sangat lemah, (2) ada hubungan antara self-reguated learning serta motivasi siswa dengan tingkat hubungan yang sedang, dan (3) terdapat hubungan antara kecemasan matematika serta self-reguated learning pada motivasi siswa dengan pengaruh $30 \%$ perubahan motivasi siswa ditentukan oleh kecemasan matematika dan selfreguated learning.
\end{abstract}

Kata kunci: Kecemasan Matematika, Self-Regulated Learning, Motivasi Siswa, Kelas Virtual

Copyright (c) 2021 Ignes Febryliani

$\triangle$ Corresponding author: Ignes Febryliani

Email Address: ignesfbryln@gmail.com (Jl. Tanah Merdeka No.20, RT.11/RW.2, Rambutan, Kec. Ps..Rebo, Jakarta Timur)

Received 28 June 2021, Accepted 13 July 2021, Published 04 August 2021

\section{PENDAHULUAN}

Matematika merupakan mata pelajaran yang abstrak. Namun, matematika juga merupakan sebuah mata pelajaran yang tanpa kita sadari memiliki hubungan yang erat dengan banyak hal disekitar kita (Octaviani, Indrawatiningsih, \& Afifah, 2021). Di kegiatan belajar mengajar matematika, siswa mengira jika matematika ialah mata pelajaran yang sulit dan rumit. Siswa merasa tidak mampu memahami konsep matematika dan menyelesaikan persoalan-persoalan matematika dan membuat siswa menjadi tidak menyukai matematika. Berdasarkan hasil Trends ini International Mathematics and Science Study (TIMSS) pada tahun 2015 ditemukan bahwa siswa Indonesia masih rendah dalam kemampuan pemahaman matematika, hal ini dikarenakan siswa masih cenderung menghafal konsep dibandingkan dengan 
memahami konsepnya (Kosiret, Indiyah, \& Wijayanti, 2021). Kurangnya kemampuan pemahaman siswa terhadap matematika mengakibatkan siswa merasa gagal dalam mencapai nilai yang maksimal sehingga munculnya rasa kecemasan dalam diri siswa. Ada sebagian siswa yang merasa kesulitan dalam proses pembelajaran matematika yang mana akan mempengaruhi nilai matematika menjadi kurang maskimal, dengan hasil nilai yang rendah juga dapat disebabkan karena siswa mengalami kecemasan matematika (Ikhsan, 2019).

Kecemasan matematis merupakan munculnya perasaan gelisah, takut dan khwatir ketika berhadapan dengan suatu permasalahan yang berkaitan dengan matematika (Santri, 2017). Sedangkan menurut (Hastuti, Eclarin, \& Dalam, 2021) kecemasan matematika adalah respon emosional yang dapat timbul apabila siswa mengalami kesulitan dalam pembelajaran matematika. Timbulnya kecemasan siswa bisa disebabkan oleh sebagian faktor mempengaruhi kecemasan siswa, yakni faktor internal ialah faktor yang timbul dalam diri sendiri contohnya adalah memiliki trauma terhadap matematika dan faktor eksternal adalah faktor yang disebabkan oleh lingkungan sekitar seperti proses pembelajaran dengan suasana tegang (Nabilah, Umam, Azhar, \& Purwanto, 2021).

Presepsi siswa yang telah mempengaruhi pikirannya membuat siswa mengalami masalah dalam pembelajaran matematika, siswa akan terus merasa bahwa dirinya tidak mampu menghadapi permasalahan matematika dan hilangnya minat belajar. Dalam penelitian (Vivin, Marpaung, \& Manurung, 2019) bahwa hilangnya motivasi siswa dalam belajar disebabkan karena siswa merasa cemas dan dipengaruhi oleh pikiran yang buruk. Kecemasan matematika sering terjadi disetiap siswa, jika kecemasan siswa tidak diatasi akan terus meningkat dan dapat mempengaruhi psikis atau fisik siswa (Sugiatno, Priyanto, \& Riyanti, 2017). Kecemasan matematika yang dialami siswa sangat perlu diperhatikan, kecemasan tersebut perlu diatasi untuk mengurangi kecemasan siswa terhadap matematika dilihat dari tingkat kecemasan siswa yang berbeda-beda.

Adapun tingkat kecemasan siswa menurut peplau (Sugiatno et al., 2017) yaitu sebagai berikut:

1. Kecemasan tingkat ringan yaitu kecemasan yang dialami dalam keseharian, seseorang masih dapat merasa tenang diikuti dengan pikiran yang positif, mampu memotivasi diri dan dapat menyelesaikan masalah dengan baik.

2. Kecemasan tingkat sedang yaitu seseorang merasa takut dengan apa yang akan terjadi, merasa sulit untuk berpikir, namun masih dapat mengikuti arahan yang telah diberikan oleh orang lain.

3. Kecemasan tingkat berat yaitu seseorang kesulitan untuk berpikir, hanya fokus dengan suatu masalah yang terjadi. Sangat membutuhkan arahan orang lain untuk mengurangi rasa cemas.

4. Panik, yaitu seseorang tidak dapat mengontrol diri, meskipun telah diberi arahan tetapi tidak dapat melakukan apapun, meningkatnya aktivitas motirik, kesulitan untuk berkomunikasi dengan orang lain.

Siswa yang mengalami kecemasan dapat disebabkan karena kurang memiliki rasa minat belajar terhadap matematika. Untuk mengurangi rasa kecemasan, siswa memerlukan self-reguated learning atau belajar mandiri dalam belajar. Self regulated learning merupakan kemandirian siswa dalam belajar atau 
siswa dapat mengatur diri pada saat belajar dengan kemampuan pemahaman yang dimilikintya tentang cara belajar yang efektif dan dapat melakukannya dengan baik dan tepat (Zamnah, 2017). Self regulated learning adalah proses melibatkan aktivitas mental yang berhubungan dengan sikap, motivasi dan lingkungannya yang dapat memberi perubahan untuk pencapaian prestasi siswa (Fitriatien \& Mutianingsih, 2020) . Pada proses pembelajara matematika guru akan menjelaskan konsep matematika dengan jelas namun siswa yang kurang mengerti dan tidak mendapat penjelasan yang lebih dari guru akan mendapatkan bimbingan belajar yang kurang karena keterbatan dengan waktu, maka dari itu siswa perlu memiliki kemandirian belajar. Self regulated leaning dalam diri siswa mempunyai minat dan dapat mengendalikan diri untuk belajar sehingga mendapat hasil belajar yang memuaskan (I, Chaidir, \& Darmayasa, 2019).

Siswa yang mempunyai strategi dalam belajar matematika akan mempengaruhi motivasi siswa dimana siswa akan memiliki keinginan yang tinggi agar mencapai tujuan belajar sesuai apa yang diharapkan. Menurut Piaget (dalam Ikram, Purwanto, \& Parta, 2021), siswa memiliki kemampuan mental untuk mengubah persepsi mereka untuk kembali ke titik awal. Motivasi belajar ialah rasa keinginan dalam diri sendiri untuk melakukan apa yang telah diharapkan (Emda, 2018). Contohnya seperti, dengan pembuatan rangkaian pembelajaran, siswa akan merasa ada dorongan dan berusaha untuk mendapatkan nilai ujian yang maskimal. Dengan demikian, motivasi diperlukan oleh siswa untuk menumbuhkan rasa inisiatif dan kreativitas, hal tersebut bermanfaat untuk menambah ketekunan belajar siswa pada proses pembelajaran (Juniayanti, 2019).

Dalam penelitian (Meiliati, Darwis, \& Asdar, 2018) dikemukakan bahwa ada hubungan secara langsung antara motivasi belajar siswa dengan self-reguated learning dalam belajar matematika. Menurut (I et al., 2019) dalam penelitiannya, self-reguated learning agar tetap mempertahkan motivasi siwa dalam belajar matematika dilakukan dengan tetap semangat dan percaya diri pada saat belajar matematika, serta memberi pengetahuan dan mengajarkan teman mengenai materi matematika. Dukungan dari lingkungan dapat meningkatkan motivasi siswa sehingga tingkat atau rendah motivasi siswa sangat berpengaruh dalam hasil belajar siswa. Hal ini selaras dengan hasil pengkajian (Emda, 2018) dikemukakan jika motivasi siswa merupakan hal penting dalam mencapai tujuan belajar, maka siswa harus memiliki motivasi baik instrinstik maupun ekstrinsik agar tujuan pembelajaran dapat tereliasasikan dengan maksimal.

Sejak adanya virus covid-19 yang telah menyebar diberbagai dunia termasuk di Indonesia pada bulan Maret 2020. Pemerintah membuat kebijakan untuk social distancing atau jaga jarak dan mengharuskan masyarakat Indonesia melakukan semua kegiatan di rumah sebagai pencegahan virus ini agar tidak menyebar luas. Begitu pun dalam proses belajar mengajar dilakukan dengan pembelajaran online dengan menggunakan teknologi dan jaringan. Penerapan pembelajaran online melalui kelas virtual membuat pembelajaran lebih efesien, bisa diakses dimana saja dan kapan saja. Pembelajaran online menggunakan kelas virtual atau istilah kelas dunia maya dimana pembelajaran tidak terikat dengan waktu dan tempat (Sudiana, Fatah, \& Khaerunnisa, 2017). Hanya saja terdapat kendala dalam pembelajara online seperti siswa merasa kesulitan dalam memahami apa yang telah dijelaskan oleh guru sehingga harus memahami materi secara mandir dan mendapatkan tugas yang cukup banyak. Hal ini dapat mengakibatkan siswa merasa 
cemas karena tidak mempersiapkan strategi pembelajaran sehingga hilangnya motivasi belajar dalam pembelajaran melalui kelas virtual. Berdasarkan pemaparan diatas, pengkajian ini mempunyai tujuan untuk mendeteksi hubungan antara kecemasan matematika dan diatur sendiri pada motivasi siswa sekolah menengah atas pada pembelajaran matematika di kelas virtual.

\section{METODE}

Jenis metode penelitian yang digunakan yaitu metode survey kuantitatif untuk mendeteksi ikatan kecemasan matematika serta self-reguated learning pada motivasi siswa dalam pembelajaran matematika secara online melalui kelas virtual. Sampel di pengkajian ini ialah siswa kelas XI sekolah menengah atas yang berada di wilayah Jakarta pada tahun ajaran 2020/2021 sebanyak 300 siswa. Teknik pengambilan sampel yang dipakai di pengkajian ini ialah purposive sampling yakni cara menentukan anggotal sampel dari populasi dengan pertimbangan terpilih agar data yang diperoleh dari hasil penelitian lebih representatif (Sugiyono, 2018). Intrumen yang digunakan dalam pengkajian ini yaitu angket kuesioner berupa pernyataan-pernyataan mengenai kecemasan matematika, self-reguated dan motivasi siswa dimana sumber pernyataan tersebut dari instrumen (Wahid, Yusof, \& Razak, 2014) dan (Guo \& Wei, 2019) yang telah dimodifikasi sesuai dengan kebutuhan penelitian. Kuesioner diberikan kepada siswa kelas XI sekolah menengah atas di wilayah jakarta secara online melalui link Google Form. Di pengkajian ini ada 3 variabel yaitu kecemasan matematika $\left(\mathrm{X}_{1}\right)$ serta self-reguated $\left(\mathrm{X}_{2}\right)$ selaku variabel bebas serta motivasi siswa $(\mathrm{Y})$ selaku variabel terikat. Pengujian hipotesis dengan menggunakan korelasi produc moment dan analisis regresi berganda. Untuk melakukan uji hipotesis akan dilakukan uji normalitas dengan KolmogorovSmirnov Test, uji linieritas dan uji multikolinearitas sebagai uji prasyarat (Basyari, 2013). Diagram alir penelitian ini dapat dilihat pada Gambar 1.

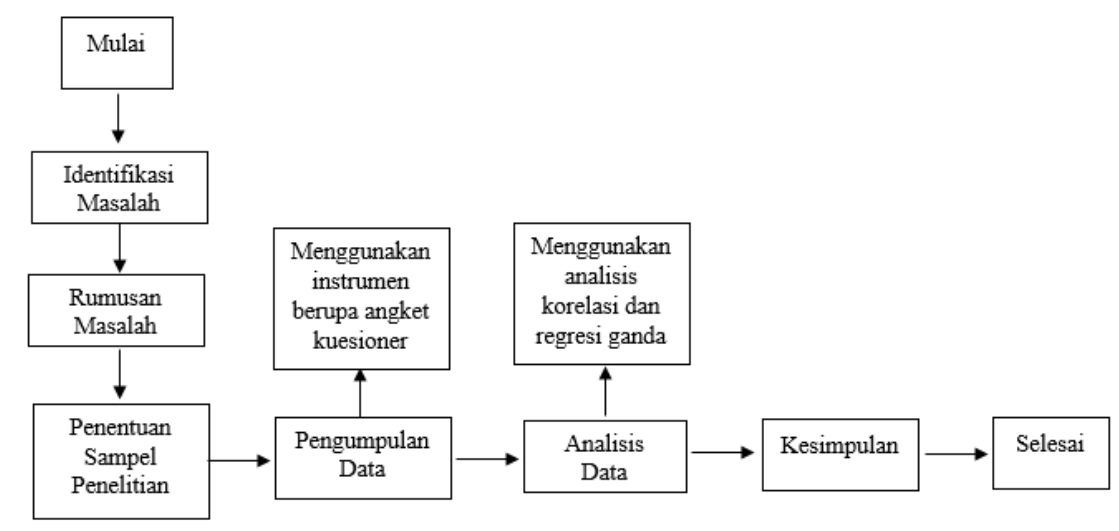

Gambar 1. Diagram Alir Penelitian

Berikut hipotesis yang dirumuskan dalam penelitian sebagai berikut:

1. Hubungan antara kecemasan matematika dengan motivasi siswa

$\mathrm{H}_{0}=$ Tidak ada ikatan antara kecemasan matematika dengan motivasi siswa

$\mathrm{H}_{1}=$ ada ikatan antara kecemasan matematika dengan motivasi siswa 
2. Hubungan antara self-reguated learning dengan motivasi siswa

$\mathrm{H}_{0}=$ Tidak ada hubungan antara self-reguated learning dengan motivasi siswa

$\mathrm{H}_{1}=$ Ada hubungan antara self-reguated learning dengan motivasi siswa

3. Hubungan antara kecemasan matematika dan self-reguated learning dengan motivasi siswa

$\mathrm{H}_{0}=$ Tidak ada ikatan antara kecemasan matematika dan self-reguated learning dengan motivasi siswa

$\mathrm{H}_{1}=$ Ada ikatan antara kecemasan matematika dan self-reguated learning dengan motivasi siswa

\section{HASIL DAN DISKUSI}

\section{Hasil}

Dalam hasil penelitian akan dikemukakan mengenai hubungan kecemasan matematika, self-reguated dan motivasi siswa sekolah menengah atas di wilayah Jakarta. Untuk memperoleh data menggunakan instrumen berupa angket kuesioner yang berisi pernyataan-pernyataan mengenai kecemasan matematika, self-reguated dan motivasi siswa dengan keseluruahan 42 butir yang diberikan secara online melalui link Google Form kepada siswa kelas XI. Angket kuesioner di pengkajian ini diukur memakai rasio likert yang diberi 5 skor. Data yang diambil sebanyak 300 responden kelas XI sekolah menengah atas di wilayah Jakarta. Variabel pada pengkajian ini akan dikerjakan pengujian hipotesis dengan memakai analisis korelasi product momen dan analisis regresi berganda.

\section{Uji Normalitas Data}

Menurut hasil uji normalitas memakai Kolmogorov-Smirnov Test dengan berbantuan software SPPS versi 25. Hasilnya didapatkan nilai sig 0,200 sehingga 0,200>0,05, nilai tersebut lebih besar dari taraf substansial 5\% atau $\alpha=0,05$ jadi bisa disimpulkan jika data hasil instrumen kecemasan matematika, selfreguated dan motivasi siswa berdistribusi normal.

\section{Uji Linieritas}

Setelah data berdsitribusi normal, dilakukan uji linieritas. Berdasarkan hasil uji liniearitas dengan bantuan software SPSS versi 25 hasil analisis dari variabel bebas yakni kecemasan siswa serta variabel terikat yakni motivasi siswa dengan taraf siginfikan 5\% atau $\alpha=0,05$ didapatkan nilai sejumlah 0,372 sampai 0,372>0,05 jadi bisa disimpulkan jika ada ikatan linier antara kecemasan matematika dan motivasi siswa.

Berdasarkan hasil uji liniearitas dengan bantuan software SPSS versi 25 ini variabel bebas yaitu kecemasan siswa dan variabel terikat yaitu motivasi siswa dengan taraf siginfikan $5 \%$ atau $\alpha=0,05$. Didapatkan nilai sejumlah 0,928 sampai 0,928 > 0,05 jadi bisa disimpulkan jika ada ikatan linier antara selfreguated dan motivasi siswa.

\section{Uji Multikolinieritas}

Dilakukan uji multikolineritas dengan menggunakan software SPSS versi 25, hasil tersebut diperoleh nilai Tolerance sebesar 0,996 maka 0,996 > 0,10 yang berarti tidak terjadi Multikolineritas. Dan nilai VIF sebesar 1,004 maka 1,004 < 10.00 yang berarti tidak terjadi Multikolineritas. Sehingga dapat disimpulkan 
bahwa model regresi dari varibel kecemasan matematika dan self-reguated terhadap motivasi siswa tidak terjadi gejala Multikolineritas.

\section{Uji Hipotesis}

Setelah melaksanakan uji normalitas, uji linieritas serta uji multikolinieritas dengan hasil data berdistribusi normal dan memiliki hubungan linier serta tidak terjadi gejala multikolineritas maka selanjutnya dilakukan pengujian hipotesis. Uji hipotesis pertama dan kedua menggunakan analisis korelasi product momen serta uji hipotesis ketiga menggunakan analisis regresi linier berganda. Dilakukan pengujian hipotesis ini bertujuan untuk menjawab dari hipotesis yang sudah dirumuskan. Berikut hasil dari pengujian setiap hipotesis:

1. Uji hipotesis pertama

Pengujian hipotesis pertama yakni ada hubungan antara kecemasan matematika $\left(\mathrm{X}_{1}\right)$ dan motivasi siswa (Y). Hipotesis pengujian yakni:

$\mathrm{H}_{0}=$ Tidak ada ikatan antara kecemasan matematika dengan motivasi siswa

$\mathrm{H}_{1}=$ Ada ikatan antara kecemasan matematika dengan motivasi siswa

Tabel 1. Hasil Analisis Korelasi Product Moment Correlations

\begin{tabular}{|ll|r|r|}
\hline & & Kecemasan & \multicolumn{1}{|c|}{ Motivasi } \\
\hline Kecemasan & Person Correlation & 1 & .076 \\
& Sig. (2-tailed) & & .189 \\
& $\mathrm{~N}$ & 300 & 300 \\
\hline Motivasi & Person Correlation & .076 & 1 \\
& Sig. (2-tailed) & .189 & \\
& $\mathrm{~N}$ & 300 & 300 \\
\hline
\end{tabular}

Berdasarkan hasil pengujian, membuktikan jika diperoleh nilai sig sejumlah 0,189 dimana lebih besar dari $\alpha=0,05$ yaitu $0,189>0,05$ artinya tidak ada ikatan antara kecemasan matematika dengan motivasi belajar. Sedangkan nilai Person Correlation (r) diperoleh sebesar 0,076 menunjukan bahwa tingkat hubungan kecemasan matematika dan motivasi belajar termasuk dalam kategori sangat lemah ataupun tidak ada ikatan. Sampai Ho diterima serta H1 ditolak. Hal ini dapat disimpulkan jika kecemasan matematika tidak memiliki hubungan dan positif terhadap motivasi siswa dan tingkat hubungannya sangat lemah.

2. Uji hipotesis kedua

Pengujian hipotesis kedua yakni ada ikatan antara self-regulaed learning $\left(\mathrm{X}_{2}\right)$ pada motivasi siswa (Y). Hipotesis pengujian yakni:

$\mathrm{H}_{0}=$ Tidak ada hubungan antara self-regulated learning pada motivasi siswa

$\mathrm{H}_{1}=$ Ada hubungan antara self-regulated learning pada motivasi siswa

Berdasarkan data yang telah dianalisis pada Tabel 2 berikut, diperoleh nilai sig sejumlah 0,000 dimana nilai itu lebih kecil dari $\alpha=0,05$ yaitu $0,000<0,05$ maka ada ikatan antara self-regulated learning dengan motivasi siswa. Sedangkan nilai Person Correlation (r) diperoleh sebesar 0,537 dengan menunjukan bahwa hubungan antara diatur sendiri serta motivasi belajar dengan termasuk dalam tingkat hubungan 
kategori sedang. Sampai Ho ditolak serta $\mathrm{H}_{1}$ diterima. Maka bisa dinyatakan jika ada ikatan positif selfreguated learning dengan motivasi siswa.

Tabel 2. Hasil analisis korelasi product moment

Correlations

\begin{tabular}{|ll|r|r|}
\hline & & Kecemasan & Motivasi \\
\hline Kecemasan & Person Correlation & 1 & .076 \\
& Sig. (2-tailed) & 300 & .189 \\
& N & 300 \\
\hline Motivasi & Person Correlation & .076 & 1 \\
& Sig. (2-tailed) & .189 & \\
& N & 300 & 300 \\
\hline
\end{tabular}

c. Uji hipotesis ketiga

Pengujian hipotesis kedua yakni ada hubungan antara kecemasan matematika $\left(\mathrm{X}_{1}\right)$ dan self-regulated learning $\left(\mathrm{X}_{2}\right)$ dan motivasi siswa $(\mathrm{Y})$. Hipotesis pengujian sebagai berikut:

$\mathrm{H}_{0}=$ Tidak ada hubungan antara kecemasan matematika dan self-regulated learning dengan motivasi siswa $\mathrm{H}_{1}=$ Ada hubungan antara kecemasan matematika dan self-reguated learning dengan motivasi siswa

Tabel 3. Ringkasan Model

\begin{tabular}{|l|l|l|l|l|}
\hline Model & $\mathbf{R}$ & $\begin{array}{l}\text { R } \\
\text { Square }\end{array}$ & $\begin{array}{l}\text { Disesuaikan } \\
\text { R Square }\end{array}$ & $\begin{array}{l}\text { Std. Kesalahan } \\
\text { Perkiraan }\end{array}$ \\
\hline 1 & $.548^{\mathrm{a}}$ & .300 & .296 & 1.887 \\
\hline
\end{tabular}

Tabel 4. ANOVA ${ }^{\mathrm{a}}$

\begin{tabular}{|ll|c|c|c|c|l|}
\hline Model & & $\begin{array}{c}\text { Jumlah } \\
\text { Kuadrat }\end{array}$ & df & $\begin{array}{c}\text { Rata-rata } \\
\text { Persegi }\end{array}$ & F & Sig \\
\hline 1 & Regresi & 454.416 & 2 & 227.208 & 63.729 & $.000^{\mathrm{b}}$ \\
\cline { 2 - 8 } & Sisa & 1057.834 & 297 & 3.562 & & \\
\cline { 2 - 8 } & Total & 1512.250 & 299 & & & \\
\hline
\end{tabular}

Tabel 5 . Hasil analisi regresi berganda

KOEFISIEN

\begin{tabular}{|ll|l|l|l|l|l|}
\hline \multicolumn{2}{|l|}{ Model } & \multicolumn{1}{|c|}{$\begin{array}{c}\text { B tidak } \\
\text { terstandarisasi }\end{array}$} & $\begin{array}{c}\text { Koefisien } \\
\text { Std Error }\end{array}$ & $\begin{array}{c}\text { Koefisien } \\
\text { Beta } \\
\text { Standar }\end{array}$ & $\mathbf{t}$ & Sig \\
\hline 1 & (Konstan) & 4.991 & .914 & & 5.459 & .000 \\
\cline { 2 - 7 } & Kecemasan & .016 & .007 & .111 & 2.279 & .023 \\
\cline { 2 - 7 } & Self-Regulated & .274 & .024 & .544 & 11.186 & .000 \\
\hline
\end{tabular}

Berdasakan tabel diatas, persamaan garis regresi ganda adalah sebagai berikut:

$$
\mathrm{Y}=0,016 \mathrm{X}_{1}+0,274 \mathrm{X}_{2}+4,991
$$

Persamaan diatas menunjukan bahwa diperoleh nilai koefisien $\mathrm{X}_{1}$ yaitu kecemasan matematika sebesar 0,016. Dimana jika nilai kecemasan matematika menambah 1 poin jadi nilai motivasi siswa sejumlah 0,016. Untuk nilai koesfisien $\mathrm{X}_{2}$ yaitu self-reguated sebesar 0,274. Dimana jika nilai self-reguated 
menambah 1 poin jadi terdapat penambahan nilai pada hasil motivasi siswa sejumlah 0,274. Berdasarkan hasil analisis regresi berganda memperlihatkan nilai koefisien determinasi $\left(\mathrm{r}^{2}\right)$ sejumlah 0,300. Maka nilai tesebut memiliki arti bahwa 30\% perubahan pada variabel motivasi siswa dapat ditentukan oleh kecemasan matematika dan self-reguated, sedangkan 70\% dijabarkan oleh variabel lain yang tidak dikaji di pengkajian ini. Hasil uji signifikan berdasarkan tabel diatas diperoleh nilai F_hitung sebesar 63,792. Sedangkan didapatkan nilai sig. sejumlah 0,000 dengan nilai $\alpha=0,05$ maka $0,000<0,05$ sehingga $\mathrm{H}_{0}$ ditolak serta $\mathrm{H}_{1}$ diterima. Dengan ini, bisa disimpulkan jika ada ikatan positif antara kecemasan matematika dan selfreguated learning terhadap motivasi belajar.

Diskusi

Hasil penelitian menyatakan bahwa tidak terdapat pengaruh kecemasan matematika terhadap motivasi siswa. Terdapat beberapa macam faktor yang dipengaruhi oleh motivasi belajar salah satunya yaitu kecemasan (Yanti, Erlamsyah, Zira, \& Ardi, 2013). Namun hal tersebut dapat terjadi karena siswa memiliki kecemasan tingkat tinggi. Siswa yang memiliki kecemasan yang tinggi dapat mempengaruhi pikiran dirinya sehingga kesulitan untuk mencari dan menemukan solusi atau memotivasi diri dalam belajar terutama proses pembelajara yang dilakukan secara online saat ini. Pada pengkajian ini bisa memperlihatkan jika tidak ada dampak kecemasan matematika dengan motivasi belajar dalam pembelajaran matematika.

Dengan adanya belajar mandiri, siswa bisa mengatur aktivitas belajar sesuai dengan kebutuhan dan tujuan belajar juga agar siswa tersebut dapat membentuk pribadi yang bertanggung jawab untuk mendapatkan hasil yang terbaik (Sagita \& Mahmud, 2019). Hal ini sesuai dengan (Aimah \& Ifadah, 2014) bahwa motivasi dalam self-reguated mempunyai peran sangat penting untuk mencapai suatu keberhasilan sehingga siswa yang mempunyai suatu permasalahan dalam proses belajar perlu diatasi dan membutuhkan motivasi yang tinggi dalam diri siswa untuk mencapai tujuan belajar. Hal tersebut sesusai dengan hasil pengkajian ini jika saat dimana semakin tinggi minat belajar mandiri siswa dalam belajar jadi akan bertambah tinggi motivasi siswa, begitu pun sebaliknya.

Dalam hasil penelitian hubungan antara kecemasan matematika dan self-reguated learning terhadap motivasi siswa terdapat pengaruh sebesar 30\%. Pada penjelasan sebelumnya, kecemasan matematika tidak memiliki hubungan dengan motivasi siswa. Namun jika dihubungkan antara kecemasan matematika dan belajar mandiri akan mempunyai ikatan secara bersama-sama pada motivasi siswa, hal tersebut menjelaskan bahwa kecemasan matematika yang berkaitan dengan self-reguated dapat mempengaruhi motivasi siswa dalam pembelajaran matematika.

\section{KESIMPULAN}

Menurut hasil analisis data diatas, peneliti menyimpukan bahwa diperoleh nilai Person Correlation (r) sejumlah 0,076 serta nilai sig sejumlah 0,189 > 0,05 jika $\mathrm{H}_{0}$ diterima serta $\mathrm{H}_{1}$ ditolak, hal ini menunjukan bahwa tidak terdapat hubungan positif antara kecemasan matematika serta motivasi siswa dengan tingkat hubungannya sangat lemah ataupun tidak ada ikatan. Kemudian, diperoleh nilai Person Correlation (r) sebesar 0,537 dan diperolah nilai Sig. (2-tailed) sejumlah 0,189>0,05 jadi $\mathrm{H}_{0}$ ditolak serta $\mathrm{H}_{1}$ diterima 
yang berarti terdapat ikatan positif antara self-reguated learning dengan motivasi belajar dalam pembelajaran matematika dan tingkat hubungannya sedang berarti dapat dinyatakan bahwa bertambah tinggi diatur senidiri jadi akan semakain tinggi motivasi siswa. Sedangkan untuk hipotesis ketiga, untuk nilai Fhitung diperoleh sebesar 63,792 dan nilai sig. diperoleh sejumlah $0,000<0,05$ jadi ada ikatan positif antara kecemasan matematika dan self-reguated dengan motivasi siswa pada pembelajaran matematika, terdapat pengaruh kecemasan matematika dan self-reguated learning terhadap motivasi siswa sebesar 30\%.

Pada hasil analisis yang telah dijelaskan, untuk peneliti selanjutnya diharapakan untuk mengambil sampel yang lebih mengerucut, menganalisis secara deskriptif dengan pendekatan kualitatif, dan atau memperhatikan model pembelajaran yang dipakai di saat kegiatan belajar mengajar matematika menjadi aktif dan mudah dimengerti serta diperlukan juga bantuan media pembelajaran yang kreatif dan menarik agar dapat mengurangi rasa kecemasan yang diderita oleh siswa di saat belajar matematika dan siswa dapat menyusun strategi dalam belajar sampai bisa menambahkan motivasi belajar siswa meskipun pembelajaran dilakukan secara online.

\section{UCAPAN TERIMA KASIH}

Pengkaji mengucapkan terimakasih kepada Allah SWT, orang tua, semua dosen Pendidikan Matematika FKIP UHAMKA, siswa-siswa beserta kepada seluruh pihak yang sudah membantu proses penyusunan di pengkajian ini sampai bisa terpecahkan dengan baik dan lancar.

\section{REFERENCES}

Aimah, S., \& Ifadah, M. (2014). Pengaruh Self-Regulated Learning terhadap Motivasi Belajar Siswa. Prosiding Seminar Nasional Dan Internasional Universitas Muhammadiyah Semarang, (2001). Retrieved from https://jurnal.unimus.ac.id/index.php/psn12012010/article/view/1187

Basyari, A. (2013). Hubungan antara minat dan prestasi belajar sejarah dengan kesadaran sejarah siswa MAN Yogyakarta III. Universitas Negeri Yogyakarta.

Emda, A. (2018). Kedudukan Motivasi Belajar Siswa Dalam Pembelajaran. Lantanida Journal, 5(2), 172. https://doi.org/10.22373/lj.v5i2.2838

Fitriatien, S. R., \& Mutianingsih, N. (2020). Peningkatan Kemampuan Belajar Mandiri pada Mata Kuliah Operasional Riset melalui Self-Regulated Learning. Mosharafa: Jurnal Pendidikan Matematika, 9, 95-106. https://doi.org/10.31980/mosharafa.v9i1.631

Guo, W., \& Wei, J. (2019). Teacher Feedback and Students' Self-regulated Learning in Mathematics: A Study of Chinese Secondary Students. Asia-Pacific Education Researcher, 28(3), 265-275. https://doi.org/10.1007/s40299-019-00434-8

Hastuti, E. S., Eclarin, L., \& Dalam, K. K. S. (2021). Kecemasan Siswa Sekolah Menengah Pertama Menyelesaikan Masalah SPLDV Pada Kelas Virtual Dalam. International Journal of Progressive Mathematics Education, 1(1), 64-84.

I, P., Chaidir, \& Darmayasa, J. B. (2019). SELF-REGULATED LEARNING PADA ASPEK MOTIVASI 
Hubungan Kecemasan Matematika dan Self-Regulated Learning terhadap Motivasi Siswa Sekolah Menengah Atas dalam Pembelajaran Matematika pada Kelas Virtual, Ignes Febryliani

SISWA KELAS VIII SMP NEGERI 2 TARAKAN DALAM BELAJAR MATEMATIKA. Asimtot: Jurnal Kependidikan Matematika, 1(2), 111-118. https://doi.org/10.30822/asimtot.v1i2.276

Ikhsan, M. (2019). Pengaruh Kecemasan Matematis Terhadap Hasil Belajar Matematika. De Fermat: Jurnal Pendidikan Matematika, 2(1), 1-6. https://doi.org/10.36277/defermat.v2i1.28

Ikram, M., Purwanto, \& Parta, I. N. (2021). Analysis of The Occurrence of Reversible Reasoning for Inverse Cases: A Case Study on The Subject Adjie. International Journal of Progressive Mathematics Education, 1(1), 1-15.

Juniayanti, D. (2019). Pengaruh Model Pembelajaran Self-Regulated Learning Berbantuan Aplikasi Google Classroom Terhadap Motivasi Belajar Ipa Siswa Sd. Jurnal Kajian Pendidikan Widya Accarya FKIP Universitas Dwijendra, (2085), 1-9. https://doi.org/10.46650/wa.10.2.772.\%25p

Kosiret, A., Indiyah, F. H., \& Wijayanti, D. A. (2021). The Use of Generative Learning Model in Improving Students' Understanding of Mathematical Concepts of Al-Azhar 19 Islamic High School. International Journal of Progressive Mathematics Education, 1(1), 16-26.

Meiliati, R., Darwis, M., \& Asdar. (2018). Pengaruh Motivasi Belajar, Self Efficacy, dan Self-Regulated Learning Terhadap Hasil Belajar Matematika. Issues in Mathematics Education, 2(1), 83-91. https://doi.org/10.35580/imed

Nabilah, E., Umam, K., Azhar, E., \& Purwanto, S. E. (2021). Kecemasan Siswa Dalam Menyelesaikan Masalah Modelling Matematika Pada Praktek Kelas Virtual. Internatioinal Journal of Progressive Mathematics Education, 1(1), 41-60.

Octaviani, K. D., Indrawatiningsih, N., \& Afifah, A. (2021). Kemampuan Visualisasi Spasial Siswa Dalam Memecahkan Masalah Geometri Bangun Ruang Sisi Datar Kemampuan Visualisasi Spasial Siswa Dalam Memecahkan Masalah Geometri Bangun Ruang Sisi Datar. International Journal of Progressive Mathematics Education, 1(1), 27-40.

Sagita, N. N., \& Mahmud, A. (2019). Peran Self-Regulated Learning dalam Hubungan Motivasi Belajar, Prokrastinasi dan Kecurangan Akademik. Economic Education Analysis Journal, 8(2), 516-532. https://doi.org/10.15294/eeaj.v8i2.31482

Santri, F. S. (2017). Ada Apa Dengan Kecemasan Matematika? Journal of Medives, 1(1), 59-65.

Sudiana, R., Fatah, A., \& Khaerunnisa, E. (2017). Kemandirian Belajar Mahasiswa Melalui Pembelajaran Berbasis Virtual Class. Jurnal Penelitian Dan Pembelajaran Matematika, 10(1). https://doi.org/10.30870/jppm.v10i1.1292

Sugiatno, Priyanto, D., \& Riyanti, S. (2017). Tingkat Dan Faktor Kecemasan Matematika Pada Siswa Sekolah Menengah Pertama. Jurnal Pendidikan Dan Pembelajaran Untan, 6(10), 217220.

Sugiyono, P. D. (2018). Metode Penelitian Kuantitatif. Bandung: Alfabeta.

Vivin, Marpaung, W., \& Manurung, Y. S. (2019). Kecemasan dan motivasi belajar. Persona:Jurnal Psikologi Indonesia, 8(2), 240-257. https://doi.org/10.30996/persona.v8i2.2276

Wahid, S. N. S., Yusof, Y., \& Razak, M. R. (2014). Math Anxiety among Students in Higher Education Level. Procedia - Social and Behavioral Sciences, 123(2014), 232-237. 
https://doi.org/10.1016/j.sbspro.2014.01.1419

Yanti, S., Erlamsyah, E., Zira, Z., \& Ardi, Z. (2013). HUBUNGAN ANTARA KECEMASAN DALAM BELAJAR DENGAN MOTIVASI BELAJAR SISWA. KONSELOR: Jurnal Ilmu Konseling, 2(1), 283-288. https://doi.org/10.24036/02013211242-0-00

Zamnah, L. N. (2017). Hubungan Antara Self-Regulated Learning Dengan Kemampuan Pemecahan Masalah Matematis Pada Mata Pelajaran Matematika Kelas Viii Smp Negeri 3 Cipaku Tahun Pelajaran 2011/2012. Teorema, 1(2), 31. https://doi.org/10.25157/.v1i2.549 